\title{
Socio-Economic Implication of Tourists' Appraisal of the Obudu Mountain Resort, Cross River State, Nigeria.
}

\author{
${ }^{1}$ Amalu, Titus E., ${ }^{2}$ Okpara, Daniel E. ${ }^{3}$ Omeje, Victor U., ${ }^{4}$ Obi Patrick O., ${ }^{5}$ \\ Okoruwa, David E. \\ ${ }^{1,4}$ Department of Geography and Environmental Science,University of Calabar, Nigeria. \\ ${ }^{2,3}$ Department of Geography, Ebonyi State College of Education, Ikwo, Ebonyi State, Nigeria. \\ ${ }^{5}$ Department of Economics, University of Calabar, Nigeria.
}

\begin{abstract}
This study examined the Socio-Economic implication of Tourists' appraisal of the Obudu Mountain Resort in Cross River state, Nigeria. Data for the study were collected through questionnaire survey, interviews, field inventory and participatory rural appraisal methods. It was observed that the people preferred the international tourists' to the domestic tourists' based on their willingness to pay more for goods and services while the domestic tourists' were preferred to the international tourists' based on their level of friendliness and association and that despite the high rate of tourists' patronage in the study area, the people are yet to enjoy the benefits of tourism in terms of development and improvement in their standard of living. Based on these findings, it is recommended that adequate steps and measures be adopted to improve the standard of living of the people through the provision of training, capacity building, credit facilities and provision of basic social amenities to reach the entire community.
\end{abstract}

Key word: Tourism, Appraisal, Destination, Development, Travel.

\section{Introduction}

Tourism provides a major economic development opportunity for many countries and a means of improving the livelihoods of its residents. Both the public and private sectors involved in tourism depend on planning to achieve sustainable tourism development that respects the local community, creates appropriate employment, maintains the natural environment, and delivers a quality visitor experience. However, many tourism destinations have pursued development without proper planning and without considering the many impacts such development will bring to the community (Hinch and Butler, 2007).

In 2009 , the tourism sector was heavily hit by the worldwide economic recession. The total number of outbound trips fell $4 \%$, the number of outbound room nights declined $7 \%$ and the sector's outbound turnover dropped $9 \%$ as prices and rates tumbled, according to IPK figures. Revenue per hotel room, for example, slumped by $26 \%$ in Asia and by $19 \%$ in Europe and North America. International tourism declined with a $4.2 \%$ fall to 880 million arrivals worldwide and a 5.7\% drop in spending to $\$ 852$ billion ( $€ 611$ billion), World Tourism Organization (UNWTO, 2011).

But the world tourism industry has proven its resilience with an unexpectedly strong comeback in the 2010. The global tourism sector grew some 5\% in 2010, according to IPK's World Travel Monitor. International travel spending grew slightly faster by $7 \%$ to $€ 781$ billion while the much larger domestic travel market also grew well by some 4\%, as shown by the latest World Travel Monitor trends for January to September 2010. This recovery was powered by emerging markets such as Asia, South America and the Middle East which all have double-digit growth rates. The large mature markets of Europe and North America, in contrast, showed only moderate growth in 2010 (World Travel Trend report, 2011).

The number of international tourists had reached a new all-time high in 2010, according to IPK and UNWTO. "There was a new world arrival record in that year," IPK president Rolf Freitag declared. International arrivals increased by 6-7\% to a new record of 935 million trips, according to the World Travel Monitor. Perhaps more importantly, this represents a $2 \%$ increase on the previous record year of 2008, thus demonstrating that international tourism has not only recovered from the 2009 slump but is already growing again in real terms in the first post-crisis year. With the current growth in some country's GDP which has metamorphosed to a drastic improvement of living standards and massive reduction of poverty rate in such countries, countries such as China, India and Brazil will grow into major tourism markets in the years to come but destinations and the tourism industry have to start now to market themselves and adapt their products and services to these millions of potential new customers, according to experts.

Today, tourism is one of the largest and dynamically developing sectors of external economic activities. Its high growth and development rates, considerable volumes of foreign currency inflows, infrastructure development, and introduction of new management and educational experience actively affect 
various sectors of economy, which positively contribute to the social and economic development of the country as a whole. Most highly developed western countries, such as Switzerland, Austria, and France have accumulated a big deal of their social and economic welfare on profits from tourism (Adeleke, 2008).

According to recent statistics, tourism provides about $10 \%$ of the world's income and employs almost one tenth of the world's workforce. All considered, tourism's actual and potential economic impact is astounding. Many people emphasize the positive aspects of tourism as a source of foreign exchange, a way to balance foreign trade, an "industry without chimney" - in short, manna from heaven. But there are also a number of other positive and negative sides of tourism's economic boom for local communities, which not always considered by advocates of tourism perspectives. (Mirbabayev and Shagazatova, 2011).

Tourism provides a major economic development opportunity for many countries and a means of improving the livelihoods of its residents. Both the public and private sectors involved in tourism depend on planning to achieve sustainable tourism development that respects the local community, creates appropriate employment, maintains the natural environment, and delivers a quality visitor experience. Tourism competitiveness is an important economic indicator. It is a major element in economic stimulation packages. Tourism is among the largest employers in most countries and also a fast-lane vehicle into the workforce for young people and women. Encouraging travel boosts consumer and business confidence; it strengthens two-way trade and promotes export income. The service economy is driving growth in most OECD countries. It represents a large part of economic activity and its importance continues to grow. Tourism, a large, complex and fragmented industry which is still very difficult to define and measure, is a key component of the service economy (30\% of international trade in services in the OECD area). In terms of revenue, OECD countries generate about $70 \%$ of world tourism activity (Travel \& Tourism Competitiveness report, 2011)

Obudu Mountain Resort in Cross River State has also experienced increased tourists visits and patronage and the host people (Becheeve community) who were mainly farmers and hunters are now becoming more interested in tourism-related activities like; jobs in the hotels, sales of food, drinks, honey, yoghurt, handcraft and other local products, engagement in transportation and tour-guiding services. The presence of tourism in the area has also provided basic amenities like; schools, electricity, security, accessible road, financial and communication facilities. However, a reconnaissance survey of the area has shown that most of these amenities are found only around the ranch urban area and these have called for a quest to answer questions like; can tourism be seen as an efficient development agent that keeps a balance between improving the standard of living and maintaining sustainable use of resources in the area and have the benefits accruing from tourism business adequately impacted or improved the lives of the people in the area. It is in this regard that this study has sought to examine the socio-economic implication of tourists' appraisal of the ranch resort by international and domestic tourists visiting the area.

\section{Stament Of Problem}

With the riot of the $7^{\text {th }}$ of January, 2007 in the study area by the local people of the area over a perceived marginalization in the tourism industry in their community, it is necessary that a study of this kind is conducted in this area to examine the current status of tourism activities as regards its development and impact of the host community.

\section{Study Objective}

The aim of this study is basically on examining the number of tourists' visiting and patronizing the ranch resort facilities and also assess the extent at which this visits has impacted on the involvement and participation of the local people in the tourism industry in-term of the benefits they enjoy for being host of the tourism edifice.

\section{Theoretical Framework}

Citizen participation theory by Kreitlow in 1960 which stipulates that local people should take part in planning, execution, utilization and assessment of social amenities or facilities designed to improve their welfare. This theory is deeply rooted in the very concept of community development which enjoins that whatever is done to improve the welfare of a people must endeavour to elicit the enthusiasm and participation of such a people. This theory is adopted by this study to ensure that the tourism industry in the area is sustainable and valuable to the government of the state, stake-holders and the host community.

\section{Socio-Economic Implication Of Tourism}

Leana and Prema (2009) in a research on "Socio-cultural transformations through tourism: a comparison of resident's perspectives at two destinations in karala, India", aimed at comparing residents perceptions on socio-cultural impacts of tourism at Kumily and Kumarakom in kerela. The research explored whether tourism activities in Kumily, with its planned intervention, are more sustainable than those in kumarakom, which are without any interventions. They study relied on in-depth interviews with beneficiary 
(respondents employed in tourism and associated occupations and non-beneficiary permanently residents in the area). The interviews were geared towards eliciting information on perceptions towards tourism and tourists, residents' involvement in tourism, community development, government's role in tourism development and the merits and demerits of tourism. To attain a holistic view, informal interviews were carried out with the officials of the tourism department; the researcher also undertook an onsite observation of tourist-host interaction and participation in events linked to tourism. A survey instrument was prepared (questionnaire) and used to buttress a better understanding of the situation in the area. The questions were a combination of multiple choices, followed by open-ended queries. The questionnaire also measured quantitative aspects such as the income of the respondent and household. The respondents were selected using purposive snowball sampling; based on this, fifty respondents were chosen at both study areas.

The study results show that all respondents in Kumily and Kumarakom held favourable attitudes towards tourists visiting their community, with most respondents in Kumily (eighty-four per cent) and kumarakom (sixty- seven per cent) preferring international tourists to domestic tourists. It was observed that international tourists spend more money and gave tips; there were instances when international tourists sponsored children's education. It was also observed that western tourists were friendlier and well mannered. Conversely, respondents criticized north Indian tourists as "rude", "arrogant" and "very bargaining". In Kumily, sixteen per cent of respondents preferred domestic tourists because they bought more local products, but in Kumarakom, twenty-two per cent of the respondents preferred domestic tourists because they did not appreciate the dress code of the international tourists. Eight per cent of the respondents also preferred domestic tourists because international tourists brought diseases like AIDS (acquired immune deficiency syndrome) to the area.

Lack of knowledge of foreign languages was also seen as a challenge. In terms of income, respondents (ninetytwo per cent) in Kumily, it was observed that tourism has led to overall community development through the boost of local economy, improving the people's standard of living, generating more jobs, providing and improving transport facilities, raising land value and improving communication skills. In Kumarakon it was observed that seventy- two per cent of the respondents disapproved of further tourism activities, noting that tourism activities had caused severe damage to the environment. Eighteen per cent of the respondents supported the continuity of tourism noting that tourism provided most job opportunity in the area, although it was realised that most tourism outfits (Vembanad Lake and hotels) dump their waste into the river and that led to depletion of the water quality and fishery resources. In terms of occupation, it was observed that the indigenes involved in tourism related jobs were mainly semi-skilled or unskilled with low remuneration; it was also observed that women gained more employment in hotels (sixty-eight per cent over men with thirty- two per cent).

In conclusion it was noted by Leena and Prema that there was a difference in the attitude towards tourism related jobs at both study areas. Most respondents (sixty-eight per cent) in Kumily disliked tourism related jobs because of the low remuneration, while in Kumarakom, seventy-two per cent of the respondents complained that indigenes were not equitably employed in tourism related jobs especially in hotels. It was also evident from the study that Kumily with its planned intervention has a more sustainable tourism development pattern than kumarakom. This intervention was successful as it considered site-specific socio-cultural features which emerged from societal transformations through awareness and the addressing of community's socioeconomic requirements through sustainable livelihoods.

Ashe (2005) in his research on "Tourism investment as a tool for development and poverty reduction", sought to investigate the trends of the tourism sector in generating jobs, particularly of the unskilled or semi-skilled variety, in the small island developing states. He noted that as the sector continues to grow it will have serious implications for the achievement of sustainable development given their fragile ecological environments, by virtue of the fact that since the tourism sector encompasses a large number of different travel-related activities, namely; (i) hospitality enterprises (ii) souvenir and craft businesses (iii) travel agencies (iv) transport enterprises (v) tour operators and tourist guides. It would bring about new challenges for host communities. The work adopted a questionnaire survey and interview with stake-holders, tourists, managers of tourist facilities and host community members in Australia and India.

Simple percentage was used to analyse the derived data and is was observed that although tourism activities in developing countries consists of both domestic and international tourism, tourism development strategy typically places the primary emphasis upon international tourists: leisure and business travellers crossing international border. This emphasis, he said, was understandable since domestic tourism leads largely to a redistribution of national income while international tourism provides the much needed foreign exchange earnings to the destination country. It was also observed that for destination areas, tourism is a major driving force for economic development because of its large potential multiplier and spill-over effects on the rest of the economy. For tourism to be sustainable, he recommended that encouragement be given to investments by local communities in various forms of tourism management through the use of low interest loans by governmental financial institutions to individuals and to private business organizations that support implementation of propoor tourism development. 
Aniah, Eja, Otu and Ushie (2009) in their work titled "patronage of ecotourism potentials as a strategy for sustainable tourism development in Cross River State, Nigeria" aimed to examine the level of domestic and international patronage of Obudu Ranch Resort between 2001-2008, tourist preference of the resort, major attractions and facilities in the resort, population threshold of the enclave communities within the study area and the purpose of tourists' visit to the Ranch Resort. Data were collected using Participatory Research Method (PRM), questionnaire survey, interview, field observation and library materials. Three hundred and forty copies of questionnaire were administered to different tourists, while the management of the ranch resort were interviewed to ascertain the level of domestic and international patronage of the ranch resort. Chi-square was used to analyze the data collected and it was discovered that more domestic tourists patronized the resort (sixtyfive thousand, three hundred and forty-one representing seventy-eight per cent) than international tourists (eighteen thousand, one hundred and sixty-one tourists representing twenty-two per cent) between 2001 and 2008. The data also revealed that most tourists visit the ranch, due to the climatic, weather condition and scenery of the environment, while 10.5 per cent of the tourists visit for research purposes; 25.2 per cent visited for business and 8.5 per cent for conference purposes. It was recommended that since sustainability of the ranch resort lies in the hands of all the stake-holders such as private individuals, the government and the local people whose livelihood depends solely on the environment, government must advocate programmes and policies that would enhance the livelihood of these local communities within these areas so as to deal with environmental problems such as unemployment, poverty, theft, problems capable of disorganizing the entire system.

\section{Study Area}

The study area is the Obudu Mountain Resort located in Obaliku Local Government Area of Cross River State. It lies between latitude $6^{\circ} 21^{1} 30^{11}$ and $6^{\circ} 22^{1} 30^{11} \mathrm{~N}$ and longitude $9^{\circ} 22^{1} 0^{11}$ and $9^{0} 22^{1} 45^{11} \mathrm{E}$, with an approximate area of $104 \mathrm{sqm}^{2}$, and a height of about $1576 \mathrm{~m}$ above sea level (Cross River State Tourism Bureau, 2010). Obudu Mountain Resort is bounded in the North by Benue state, North-East by the Republic of Cameroon, to the South-East by Boki Local Government Area in Cross River State of Nigeria. Seven villages within the Obudu plateau (Apah-ajili, Okwamu, Keji-oku, Kegol, Okpazenge, Anape, Old Ikwette) makes-up the focus of this study (Figure 1).

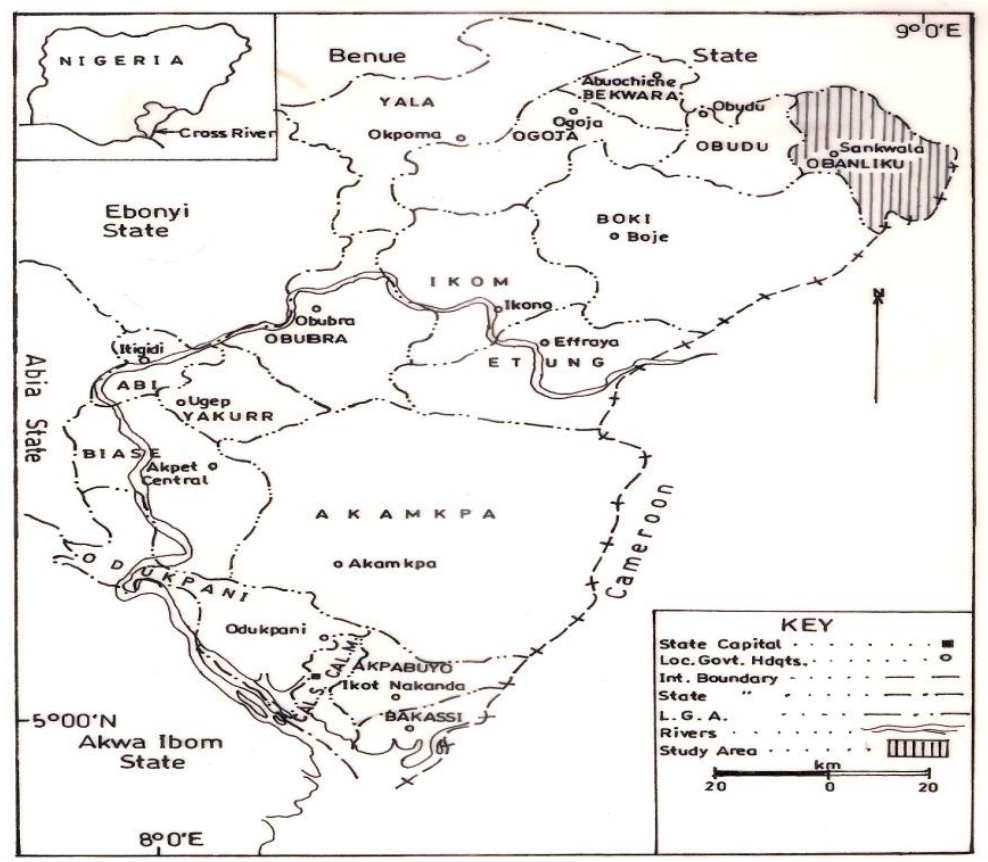

FIGURE 1: Map of Cross River State showing Obanliku Local Government Area

Source: Calligraphic Unit, University of Calabar (2011)

\section{Methodology}

Data collected for this study was based on the study objective, with information on the perceived benefit of tourism to the local people in-terms of their involvement in tourism related activities in the study area and the impact of tourists' visit to the area with special emphasis on the number of arrivals in-terms of the number of international and domestic tourists' that patronized the resort facilities.

Primary and secondary sources of data collection were used to obtain data for this research. The primary sources involved the use of questionnaire, interviews and the researcher's direct field observations. The 

secondary sources involved information from textbooks, journals, State Tourism Bureau and the management of Obudu Mountain Resort hotels.

The population of the study is made up of the house-hold heads in the study area. Information was also gathered from women and youths who were involved in tourism and non-tourism related activities. They are mainly community people who are bread-winners of their families and are involved in economic activities within the study area. All house-hold heads in the area were purposely adopted for this study questionnaire survey process because this category of people makes up the population involved in economic activities in the area, while the choice to use all the house-hold heads in the area was based on the consideration of the limitation of the number of house-holds present in the area. The total number of house-holds used for this study is two hundred and twenty-five (225) in the study area. The method of data collection was through questionnaire administration, interviews and participatory research method (PRM).

TABLE 1: Population and sample size

\begin{tabular}{|l|l|l|l|}
\hline S/N & Village & $\begin{array}{l}\text { *POPULATION } \\
(2009)\end{array}$ & $\begin{array}{l}\text { +(TOTAL } \\
\text { HOUSEHOLDS })\end{array}$ \\
\hline 1 & Anape & 397 & 51 \\
\hline 2 & Okpazenge & 266 & 30 \\
\hline 3 & Kegol & 338 & 35 \\
\hline 4 & Keji-uku & 261 & 28 \\
\hline 5 & Okwamu & 132 & 23 \\
\hline 6 & Apah-Ajili & 195 & 24 \\
\hline 7 & Old-Ikwette & 337 & 34 \\
\hline & Total & 1926 & 225 \\
\hline
\end{tabular}

Sources: * Development in Nigeria (2010), + Fieldwork, (2011).

VIII. Data Presentation, Analysis And Discussion Of Findings

1.1 International and domestic tourists' patronage of the ranch hotel

TABLE 2: International and domestic tourist patronage of the ranch hotels(2000-2009)

\begin{tabular}{|c|c|c|c|c|c|}
\hline \multirow[b]{2}{*}{ MONTH } & \multicolumn{2}{|c|}{ INTERNATIONAL TOURISTS } & \multicolumn{2}{|c|}{ DOMESTIC TOURISTS } & \multirow[b]{2}{*}{ TOTAL } \\
\hline & $\begin{array}{ll}\text { NUMBER } & \text { OF } \\
\text { TOURISTS } & \\
\end{array}$ & $\begin{array}{l}\% \text { OF } \\
\text { TOURISTS }\end{array}$ & $\begin{array}{ll}\text { NUMBER } & \text { OF } \\
\text { TOURISTS } & \\
\end{array}$ & $\begin{array}{l}\% \\
\text { TOURISTS }\end{array}$ & \\
\hline JAN & 99 & 17 & 473 & 83 & 572 \\
\hline FEB & 105 & 20 & 426 & 80 & 531 \\
\hline MAR & 111 & 22 & 402 & 78 & 513 \\
\hline APR & 157 & 19 & 659 & 81 & 816 \\
\hline MAY & 103 & 19 & 436 & 81 & 539 \\
\hline JUNE & 98 & 21 & 366 & 79 & 464 \\
\hline JULY & 90 & 23 & 308 & 77 & 398 \\
\hline AUG & 100 & 23 & 331 & 77 & 431 \\
\hline SEPT & 385 & 33 & 783 & 67 & 1168 \\
\hline OCT & 153 & 22 & 540 & 78 & 693 \\
\hline NOV & 152 & 21 & 573 & 79 & 725 \\
\hline DEC & 258 & 20 & 1011 & 80 & 1269 \\
\hline TOTAL & 1811 & 22 & 6308 & 78 & 8119 \\
\hline
\end{tabular}

Source: Records obtained from Obudu Ranch Resort Hotels (2011)

The study result shows that domestic tourists have more patronage to the ranch hotels than international tourists. The data reveals that a total of six thousand, three hundred and eight (6308) domestic tourists patronized the hotels representing 78 per cent of the total recorded tourist patronage from 2000 to 2009; while one thousand, eight hundred and eleven (1811) international tourists patronized the hotel representing 22 per cent of all tourists' patronage.

From the questionnaire survey and interview conducted in the study area, it was discovered that notwithstanding the advantage the number of domestic tourists' that patronized the ranch resort had over that of the international tourists, the local people involved in tourism related activities in the area reported to prefer and enjoy better remuneration from the international tourists' as they spent more money on goods and services.

Studies by Key and Pillai, (2006); Jenny, (2001) and Ashley, (2000), reveals that domestic tourists record more visits to tourist destinations based on factors like; distance, climate, language, culture and security. 
5.2 Patronage of the ranch facilities

TABLE 3: Monthly average income generated from facilities (2009)

\begin{tabular}{|l|l|l|}
\hline FACILITIES & FRQUENCY. & $\begin{array}{l}\text { MONTHLY } \\
\text { AVERAGE }(\mathrm{N})\end{array}$ \\
\hline RANCH HOTEL & 159 ROOMS & $3,526,175.00$ \\
\hline $\begin{array}{l}\text { INDIGENOUS } \\
\text { HOTEL }\end{array}$ & 30 ROOMS & $231,148.30$ \\
\hline $\begin{array}{l}\text { SWIMMING } \\
\text { POOL }\end{array}$ & 1 & $43,545.42$ \\
\hline $\begin{array}{l}\text { NATURE } \\
\text { GARDEN }\end{array}$ & 1 & $22,475.83$ \\
\hline WATER FALL & 1 & $14,780.00$ \\
\hline $\begin{array}{l}\text { LAWN TENNIS } \\
\text { COURT }\end{array}$ & 2 & $22,562.00$ \\
\hline LOCAL BAR & 2 & $30,124.17$ \\
\hline $\begin{array}{l}\text { RESORT } \\
\text { RESTAURANT }\end{array}$ & 1 & $20,7602.5$ \\
\hline $\begin{array}{l}\text { LOCAL } \\
\text { RESTAURANT }\end{array}$ & 3 & $46,349.17$ \\
\hline RESORT BAR & 2 & $47,965.83$ \\
\hline $\begin{array}{l}\text { CANOPY } \\
\text { WALK WAY }\end{array}$ & 1 & $12,572.00$ \\
\hline MARKET & 1 & $55,896.67$ \\
\hline GAMES HALL & 1 & $15,716.67$ \\
\hline CABLE CAR & 34 & $76,241.67$ \\
\hline GOLF CAR & 12 & $2,383.33$ \\
\hline TOTAL & & $4,355,538.56$ \\
\hline
\end{tabular}

Source: Author's field Survey (2011)

Table 3 shows that the highest recorded monthly average income is gotten from accommodation, recording an average of $\mathrm{N3}, 526,175.00$ monthly while the least patronage is recorded against the golf-car with $\mathrm{N} 2,383.33$ as monthly generated income. This is to show that accommodation is the month important facility in-terms of comfort and patronage in a tourist resort. It was also realised that cost of usage of most of this facilities is a push factor to the patronage of the facilities.

Table 4: Resident's scale of preference over the patronage pattern of International and domestic tourists' in the ranch resort.

\begin{tabular}{|l|l|l|l|l|l|l|l|l|}
\hline & \multicolumn{9}{|l|}{ Patronage } & $\begin{array}{l}\text { Prefers } \\
\text { Int. } \\
\text { Tourists' }\end{array}$ & $(\%)$ & $\begin{array}{l}\text { Prefers } \\
\text { Dom. } \\
\text { Tourists' }\end{array}$ & $(\%)$ & $\begin{array}{l}\text { Prefers } \\
\text { Int. } \\
\text { Tourists' }\end{array}$ & $(\%)$ & $\begin{array}{l}\text { Prefers } \\
\text { Dom. } \\
\text { Tourists' }\end{array}$ & $(\%)$ \\
\hline Anape & 40 & 78 & 11 & 22 & 21 & 41 & 30 & 49 \\
\hline Okpazenge & 18 & 60 & 12 & 40 & 10 & 33 & 20 & 67 \\
\hline Kegol & 20 & 57 & 15 & 43 & 9 & 26 & 26 & 74 \\
\hline Keji-uku & 20 & 71 & 8 & 29 & 8 & 29 & 20 & 71 \\
\hline Okwamu & 15 & 65 & 8 & 35 & 9 & 39 & 14 & 61 \\
\hline Apah-Ajili & 14 & 58 & 10 & 42 & 8 & 33 & 16 & 67 \\
\hline $\begin{array}{l}\text { Old- } \\
\text { Ikwette }\end{array}$ & 26 & 77 & 8 & 23 & 8 & 24 & 26 & 76 \\
\hline Total & 153 & 68 & 72 & 32 & 73 & 32 & 152 & 68 \\
\hline
\end{tabular}

Source: Researcher's field survey, 2011.

From table 4, it is being discovered that the local people in the area prefers the patronage strength of the International tourists' where their opinion poll stood at 153 for international tourists' to 72 for domestic tourists' which represents 68 percent for international tourists' and 32 percent for domestic tourists' respectively, reasons being that, the international tourists' at every point in time were ready to pay for or buy 
Socio-Economic Implication Of Tourists' Appraisal Of The Obudu Mountain Resort, Cross River goods and services without much bargain which was the case for domestic tourists' who always claimed they were being charged too much for goods and services and that the international tourists' paid and purchased goods and services at a higher cost since they deal with foreign currencies.

The table further showed that the local people (host) preferred the domestic tourists' in-terms of association and friendliness where 73 respondents out of 225 was noticed to prefer international tourists' and 152 persons preferring the domestic tourists' which represents 32 percent to 68 percent respectively. The reasons for this, was discovered to be that, the international tourists' haven come from a very different environment found some difficulty in mingling and associating freely with the local people while the domestic tourists' got more acquainted with the environment and people more easily and faster.

\section{Discussion Of Findings}

In a bid to investigate the implication tourists' visits has on the general development of the tourism industry in Obudu Mountain resort and its host, this study therefore examined the level of participation (in-terms of benefits-sharing) of the community in tourism related activities in the area.

It is discovered that the Obudu Mountain resort serves as a very important revenue point and imagebuilding mechanism to the state and of such it generates a huge income to the government of the state.

In assessing the impact of tourism on the living standards of the people, it is observed that although basic social amenities like; tarred roads, electricity, potable water, security, medical facilities, communication facilities, schools, transportation services and financial facilities (ATM) are provided, these facilities are mainly found noticeably around the tourism business centre (TBS) and therefore it could be said that the facilities are basically put in place to ensure the satisfaction and comfort of tourists visiting the area. Apart from Keji-oku, which is located at the heart of the (TBC), other adjoining villages do not feel the presence or relevance of such facilities.

In terms of income, it is observed that tourism in the area has created impact on the household income but the people complained that they still could not afford most basic necessities of life to live up to the standard which the emergence of tourism in their community has inflicted on them by increasing their cost of living or life style. The study also reveals that there was a steady increase in cost of living in the area as this also transformed to an adverse increase in house-hold expectancies or running cost in the area. Just as Cole (2006) and Goodwin (2008), had identified one major impact of tourism which they said "increases the income level among the host people"; this increment is also felt in the level of employment of indigenes in the various tourism servicing industries in the area with a recorded 51 per cent of employed indigenes in the hotels over 49 per cent of non-indigenes.

This is a confirmation of Honey (2008); Jamieson et, al. (2004) observations that the tourism industry brings about the establishment of allied industries which in-turn generates more employment opportunities to the people of the area.

Tourism development in the area has also witnessed an increase in patronage of the hotels by tourists visiting the area with an increase from five hundred and ninety-three (593) tourists in 2000 to one thousand, three hundred and eighty-three (1383) in 2009.

Table 2, shows the difference in patronage by international and domestic tourists in the ranch Resort. It is observed that there has been a steady increase in patronage of the Ranch resort hotels since 2000 to 2009 and the table further show that domestic tourists have had more patronage of the Ranch Resort hotels.

It is also observed that domestic tourists patronized the resort more than international tourists'. The data further reveals that the total number of domestic tourists that patronized the resort between 2000 and 2009 is six thousand, three hundred and eight $(6,308)$, representing 78 per cent while the total number of international tourist is one thousand, eight hundred and eleven $(1,811)$, representing 22 per cent of the entire tourists that patronized the resort.

We also discovered that the local people in the area preferred and enjoyed individual patronage from the international tourists' than their domestic counterpart and it was observed that 68 percent of the respondents preferred the patronage of international tourists' to 32 percent for domestic tourists owing to the fact that they paid more for goods and services while 68 percent of the respondents preferred the domestic tourists' in-terms of their level of association and friendliness over 32 percent of the respondents who preferred the international tourists'.

\section{Conclusion}

With the steady increase in tourist's patronage since 2000 to 2009 in the area, the study has revealed that if tourism is properly planned, it could stimulate equitable development of the people and the host communities. It is, therefore, wished that the authorities concerned should as a matter of urgency plan how tourism can be used as a catalyst towards human and community development in the state. Based on the findings outlined above, the following recommendations are hereby suggested; 
(i) People of the study area should be encouraged to go to school, through the award of scholarships or bursaries; the government should also establish technical colleges and training centre where required manpower can be developed and those trained can be employed in managerial and technical positions in the various tourism industries in the area.

(ii) Since skill acquisition projects help to provide required manpower and skills to ensure transmission of proper managerial techniques in individuals, skills acquisition program and credit facilities should be put in place to aid the people towards increased participation in the tourism industries in their vicinity.

(iii) Government should consider stepping up their effort to extend the provision of basic social amenities to adjoining villages in the area, especially as these constitutes the basic requirements for a successful tourism operation. There is a need for government to include the community people in all the stages of tourism development (planning, implementation, evaluation and benefit-sharing) in the area. This will increase the people's interest in tourism, improve their level of hospitality to tourists and also increase their level of participation in ensuring the sustenance of tourism in the area.

(iv) Above all, community tourism which will ensure wider community involvement should be encouraged. This will enhance the development of more socially acceptable guidelines for community development, where the benefits accruing from tourism will be used to achieve the goal of bringing prosperity to host communities in the vicinity of tourism enterprises.

(v) More and an effective advertisement and marketing strategies be adopted and put in place through the electronic and print media and even the exploration of internet facility be adopted to ensure wide publicity and increased patronage of the ranch facilities.

(vi) Adequate and effective security system/network should be established to guarantee total safety of life and properties of tourists to ensure and encourage more visits and longer duration of stay by tourists.

\section{References}

[1] Aniah, E. J., Eja, E. I., Otu, J. E. \& Ushie, M. A. (2009). Patronage of ecotourism potentials as a strategy for sustainable tourism development in Cross River State, Nigeria. Journal of Geography and Geology, 1 (2), 20-27.

[2] Aref, F., Gill, S. \& Aref, F. (2011). Tourism development in local communities: As a community development approach. Journal of American Science, 6 (2), 155-161.

[3] Ashe, J. W. (2005). Tourism investment as a tool for development and poverty reduction: The experience in Small Island Developing States (SIDS), Barbados. Paper presented at the Commonwealth Finance Ministers meeting, New York, September 17.

[4] Ashley, C. (2000). The impacts of tourism on rural livelihood: Namibia's experience. Overseas Development Institute (ODI), London Working Paper, 128, 5-31.

[5] Bola Olusola Adeleke, "Peace and Tourism in Nigeria." Paper commissioned for 2008 Travelers'

[6] Philanthropy Conference, Arusha, Tanzania. Available from the Center for Responsible Travel (www.responsibletravel.org).

[7] Cole, S. (2006). Cultural tourism: Community participation and empowerment. New York: John Wiley \& Sons.

[8] Cross River State Tourism Bureau (2010). Tourism in Cross River, the journey so far. Calabar: Tempo Project report.

[9] Development In Nigeria, (2010). Can tourism help reduce poverty in Nigeria? Overseas Development Institute Briefing Paper, 4, $12-24$.

[10] Goodwin, H. (2008). Tourism, local economic development and poverty reduction. Applied Research in Economic Development, 5 (3), 55-64.

[11] Hinch, T. \& Butler, R. (2007). Tourism and indigenous people: Issues and implications. Amsterdam: Butterworth- Heinemann.

[12] Honey, M. (2008). Ecotourism and sustainable development: Who owns paradise? Washington DC: Island Press.

[13] ITB Berlin Convention (2011). World Travel Trend Report 2010/2011. Messe Berlin. www.itb.library.com.

[14] Jamieson, W., Goodwin, H. \& Edmunds, C. (2004). Contribution of tourism to poverty alleviation: Pro-poor tourism and the challenge of measuring impacts. Delhi: United Nations Economic and Social Commission for Asia and the Pacific, UN ESCAP.

[15] Jenny, M. (2001). Local change of behaviour towards tourism in Mulu National Park, Malaysia. Hornbill, 5 (2), $22-28$.

[16] Key, C. \& Pillai, V. K. (2006). Community participation and tourism attitudes in Belize. Journal of Environment and Tourism, 2 (2), 8-15.

[17] Leena, M. S. \& Prema, R. (2009). Socio-cultural transformations through tourism: A comparison of residents 'perspectives at two destinations in Kerala, India. Journal of Tourism and Cultural Change, 7 (1), 5-21.

[18] Mirbabayev, B. and Shagazatova, M. (2011) The Economic and Social impact of Tourism. Global journal. Vol.1 No.2, pp.25-37.

[19] Overseas Development Institute (ODI) (2006). Can tourism help reduce poverty in Africa? London: Overseas Development Institute.

[20] Tourism Master Plan (2002). Strategy and actions. Dere Salaam: Ministry of Natural Resources and Tourism.

[21] UN World Tourism Organization (UNWTO, 2011), Tourism Highlights, 2008 Edition (Madrid: UNWTO, 2008) and World Tourism Barometer (June 2009).

[22] UNCTAD, World Investment Report 2007: Transnational Corporations, Extractive Industries and Development (unctad.org/Templates/WebFlyer.asp?intItemID=4361\&lang=)

[23] United Nations Conference on Trade and Development (UNCTAD) (2007). FDI in Tourism: The development dimension, UNCTAD current studies on FDI and development. New York: United Nations.

[24] World Trade Organisation (WTO) (2010). Tourism and poverty alleviation: Recommendation for action Spain. Madrid: World Trade Organisation. 